\title{
POVERTY REVISITED: PRESENTING POVERTY THE NORMATIVE WAY
}

\author{
Oluwaseun S. Saidu ${ }^{1}$
}

\begin{abstract}
This paper delves into the issue of poverty from the Islamic perspective. Particularly, the author aims to present the concept of poverty in the "normative" [as it ought to be] way and enquires whether concerns regarding poverty, or the state of poverty, is for Muslims a justified issue. In other words, are the absence of material supplies and wealth widely seen today in a negative light or is it the real or true poverty - as represented by the Qur'ān (Allah) and (Sunnah) His Messenger (PBUH) - really the poverty worth focusing on? Without adequately understanding what poverty is there cannot be effective solutions and interventions. Employing scriptural evidence vis-à-vis Islamic legal reasoning, we argue that normative poverty, in accordance with the Islamic tradition, is the real poverty and not material poverty.
\end{abstract}

Keywords: normative poverty, true poverty, therapeutic antidote, spiritual emptiness, poverty fear, discontentment

\footnotetext{
Dr. Saidu, an alumnus of The University of Manchester is independent. He is involved in community service of human development as well as social welfare. His research interest amongst others is in the area of Islamic interpretation of social sciences.sulaimanibnsaidu@alumni.manchester.ac.uk
} 


\section{INTRODUCTION}

Poverty appears to be the proverbial fear that grips all, making mankind focus mainly on worldly affairs and pay less attention to matters of the soul (i.e. remembrance of Allah). This is true of Muslims and non-Muslims alike. Confirming this are the numerous international organizations, governments, and non-profits who base their policies and activities towards the reduction of poverty. This raises the question as to how Muslims should conceive poverty, what dimensions of poverty should be of concern, whether poverty as widely construed is really a problem, and whether or not we are threatened by poverty, as Allah says in the Qur' $\bar{a} n$ :

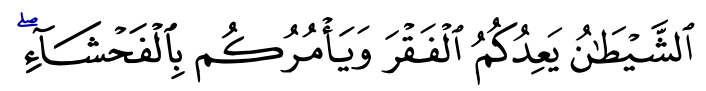

"Satan threatens you with poverty and orders you to do to bad deeds..."

(Surah al-Baqarah, 2: 268)

Against this backdrop, we revise the concept of poverty towards a normative conception, alleviating the popular fear of material poverty by presenting an alternative and proceeding to offer therapeutic solutions for the former. The paper concludes with a definitive statement on the issue of poverty.

\section{POVERTY RE-EXPLAINED}

Arguably, understanding correctly the antithesis of something or a phenomenon might make the comprehension of such a phenomenon become easy. To this end, it has been narrated by Abū Hurayrah that the Prophet (PBUH) said:

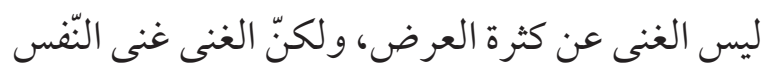

"Riches does not mean having a great amount of property, but riches is self-contentment..." 2

Deducible from the hadith is that the direct antonym of richness is poverty, which is defined here as a lack of self-contentment or discontent of the heart. Further clarifying this position is the hadìth narrated by Abū Hurayrah wherein Allah's Messenger (PBUH) is reported to have said the following:

Sahīh al-Bukharì, hadīth narrated by Abū Hurayrah, Chapter of Making the Hearts go Tender, no. hadīth 35 . 


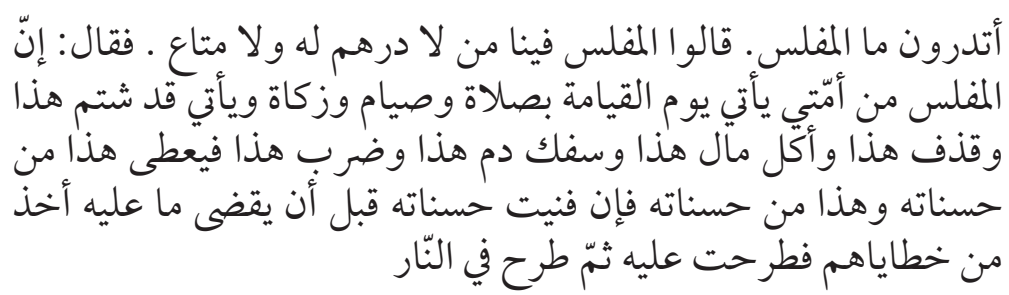

"Do you know who is bankrupt? They (the Companions of the Holy Prophet) said: 'A bankrupt man amongst us is one who has neither dirham with him nor wealth' He (the Holy Prophet) said: 'The bankrupt of my Ummah would be he who would come on the Day of Resurrection with prayers and fasts and zakāh but (he would find himself bankrupt on that day as he would have exhausted his funds of virtues) since he hurled abuses upon others, brought calumny against others and unlawfully consumed the wealth of others and shed the blood of others and beat others, and his virtues would be credited to the account of one (who suffered at his hand). And if his good deeds fall short to clear the account, then his sins would be entered in (his account) and he would be thrown in the Hell-Fire... ", 3

Likewise deducible from this hadith is that bankruptcy means to be entrenched in sinful acts or evil even in the face of fulfilling ritualistic religious obligations - ultimately leading to the punishment in the Hellfire. Analysing further, it follows that one might have material wealth and yet be poor and discontent, whereas on the other hand a situation might be characterized by the absence of material wealth yet be free of poverty (i.e. being rich in contentment). Viewed from this perspective, poverty should thus be effectively construed as a state of mind which breeds discontent materially cum spiritually and condemns as well as plunges the assumer of such a state in malaise and hopelessness in this world and in the next. However, richness connotes a state of mind filled with contentment, spiritually and materially, elevating the individual to a blissful happiness and positive relevance for this world and the hereafter

Șaḥih Muslim, hadīth narrated by Abū Hurayrah, Chapter of Virtue, Enjoining Good Manners, and keeping ties of Kinship, no. hadith 77. 


\section{FEAR OF NORMATIVE POVERTY: THE JUSTIFIABLE POVERTY FEAR}

The words im 'laqin, faqra, miskin, muflis are construed by many to denote the physical absence of material goods which creates fear in the minds of many. However, given the aforementioned exposition, these are not necessarily justifiable fears. Rather, the fear of normative poverty (true poverty) is a fear that is required by Muslims so that he or she can prevent himself or herself from destruction in this world and in the next. This assertion is backed by the hadith narrated by 'Amr Ibn 'Awf where he reported that the Prophet (PBUH) said:

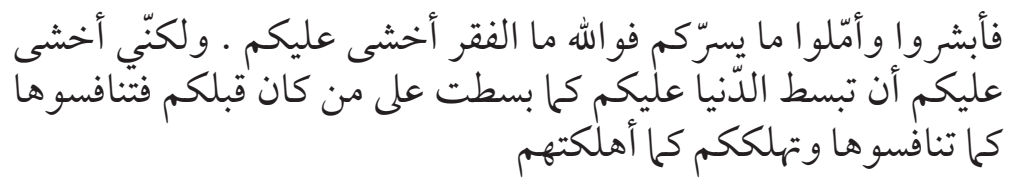

“...... he happy and be hopeful of that which gives you delight. By Allah, it is not poverty that I fear for you, rather what I fear for you is that worldly riches may be given to you as they were given to those who came before you, and you will compete for them with one another as they competed with one another, and you will be destroyed as they were destroyed..." 4

More directly, Abū Darda' reported that:

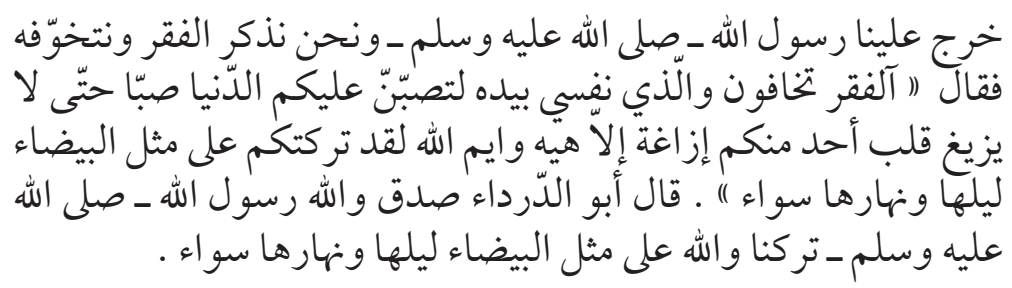

"The Messenger of Allah (PBUH) came out to us when we were speaking of poverty and how we feared it. He said: 'Is it poverty that you fear? By the One in Whose Hand is my soul, (the delights and luxuries of) this world will come to you in plenty, and nothing will cause the heart of anyone of you to deviate except that. By

Șaḥị̣ Muslim, hadīth narrated by 'Amr b. 'Awf, Chapter of Ascetism and tendering of hearts, no. hadīth 9. 
Allah, I am leaving you upon something like Bayda (white, bright, clear path) the night and day of which are the same... ", 5

It is in fact true that the absence or the inadequacy of material goods for a human being is a virtue. The Prophet is reported to have said:

$$
\text { اطّلعت في الجِّة فرأيت أكثر أهلها الفقراء }
$$

"I looked into paradise and found that the majority of its dwellers were the poor people...." 6 (i.e. those who were actually rich in the real sense of it in the world as a result of being free from normative poverty.)

Abū Dharr reported that the Prophet (PBUH) admonished him to love the poor and to keep close to them:

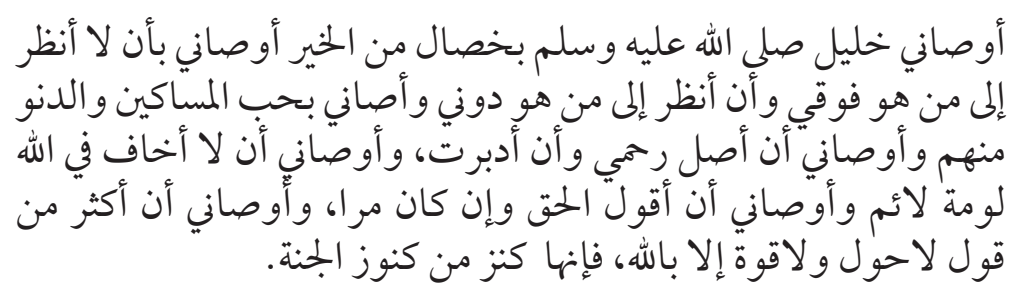

"My friend the Prophet (PBUH) admonished me with respect to some good mannerisms, that; I should not look at those above me, but look at those below me (in worldly matters), and also admonished me to love the poor and be close to them and that I should keep ties of kinship, that even if they (my kins) desert me, I should still keep ties with them and that I should not fear the blame of the blamers with respect to fulfilling Allah's rights and that I should speak the truth even if it is "bitter" ( no matter what) and that I should be prolific saying, there is no power or strength, except Allah, (for) it is a tree in paradise..." 7

$5 \quad$ Sunan Ibn Mājah, hadīth narrated by Abū Darda', Chapter of Sunnah, no. hadìth 5. The hadìth is also reported in Sunan Ibn Mājah 3997: Book 36, hadìth 72 and in Jami` at-Tirmidhi; Book 37, hadìth 2650.

6 Sahīh al-Bukharī; hadìth narrated by 'Imran bin Husayn, Chapter of Making the Hearts go Tender, no. hadìth 38.

7 Sahịh Ibn Hibban, hadīth narrated by Abū Dharr, Chapter on the remembrance of the Instruction of Prophet on keeping ties of Kinship and severing ties of Kinship, no. hadith 449. This hadith is also reported in Musnad Ahmad 21415, 21517. 
The Prophet (PBUH) is also reported by Abū Sa'īd al-Khudrī to have said in his supplication:

$$
\text { اللّهمّ أحيني مسكينا وأمتني مسكينا و احشرني في زمرة المساكين }
$$

"O Allah, cause me to live poor and cause me to die poor, and gather me among the poor (on the Day of Resurrection)..." 8

This is the statement upon which Abū Sa'īd al-Khudrī concluded that the love of the poor or loving the state of absence of material wealth is a virtue. ${ }^{9}$ The Prophet (PBUH) in fact sanctioned poverty over being rich in an hadith narrated by Narrated Sahl bin $\mathrm{Sa}^{\prime} \mathrm{d}$ al-Sa'id wherein:

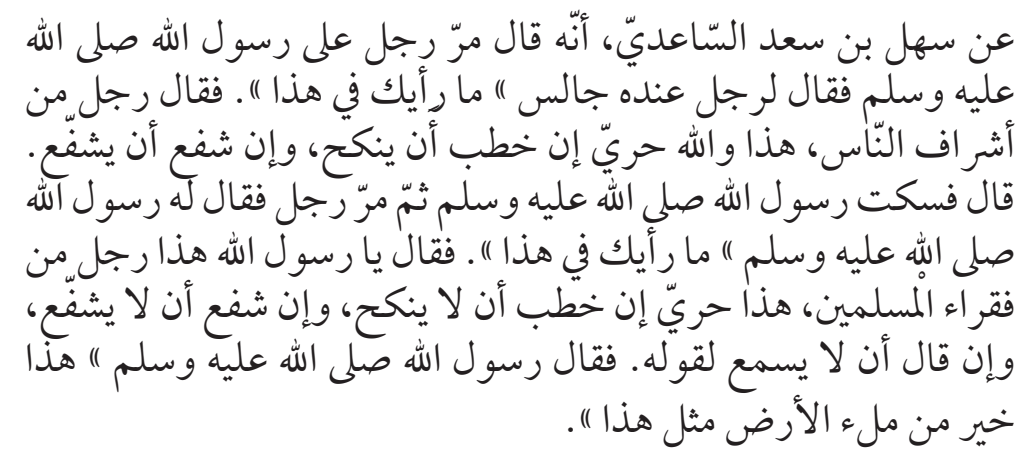

"A man passed by Allah's Messenger (PBUH) and the Prophet (PBUH) asked a man sitting beside him, "What is your opinion about this (passer-by)?" He replied, "This (passer-by) is from the noble class of people. By Allah, if he should ask for a lady's hand in marriage, he ought to be given her in marriage, and if he intercedes for somebody, his intercession will be accepted. Allah's Messenger (PBUH) kept quiet, and then another man passed by and Allah's Messenger (PBUH) asked the same man (his companion) again, "What is your opinion about this (second) one?" He said, "O Allah's Messenger (PBUH)! This person is one of the poor Muslims. If he should ask a lady's hand in marriage, no-one will accept him, and if he intercedes for somebody, no one will accept his intercession, and if he talks, no-one will listen

8 Sunan Ibn Mājah, hadīth narrated by Abū Sa‘īd al-Khudrī, Chapter of Ascetism, no. hadìth 4265. This hadīth is also reported in Mustadrak al-Hākim, 7911.

9 For similar evidences for virtuosity of material poverty, please read the biographies of the companions of the Prophet (PBUH) by al-Hamid particularly the stories of Mus'ab Ibn 'Umayr, Sa'id Ibn Āmir al-Jumahi and Ubay Ibn Ka'ab. 
to his talk." Then Allah's Messenger (PBUH) said, "This (poor man) is better than such a large number of the first type (i.e. rich men) as to fill the earth..." 10

Further buttressing the virtuosity of poverty assertion is the account:

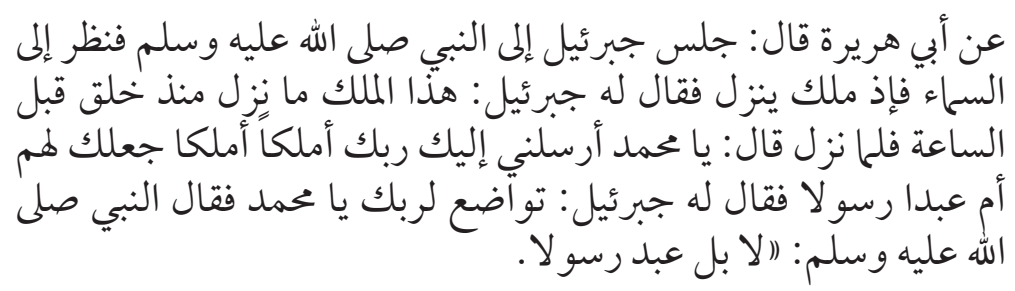

"Jibreel sat down with the Prophet (PBUH), looked at the heavens and said; this angel (coming down) has never come down since he was created and will not come down (again) until the day of judgement. When the angel came down, he said O'Prophet, Your Lord has sent me to you (to ask you that) are you a (Prophet-) King or a Servant-Messenger, Jibreel then said, humble yourself before your Lord, He(PBUH) said, No, I am a Servant-Messenger.

...reaching us revealing that the Messenger (PBUH) was given the option to choose between been a Prophet-King or a Servant-Messenger to which he chose to be the Servant-Messenger, humbling himself to Allah, Exalted is He. ${ }^{11}$

In other words, he chose material poverty (not normative poverty) whilst being a Prophet of Allah. Similarly, Abū Umamah reported that the Prophet (PBUH) said:

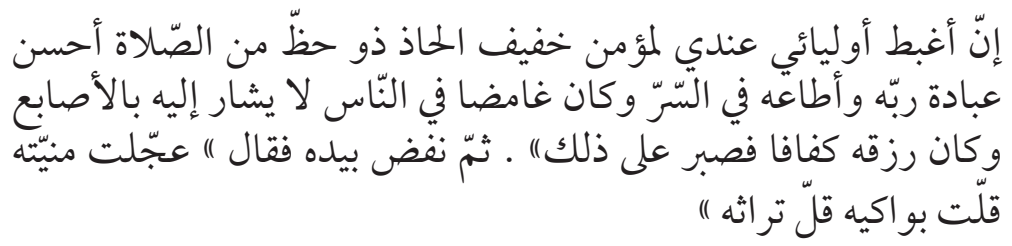

"My Lord offered to make the plain and pebbles of Mecca gold, but I said: 'No, my Lord! Rather I (would prefer) to eat my fill one

10 Sahịh al-Bukharī, hadīth narrated by Sahl bin Sa'd al-Sa'id, Chapter of Making the Hearts go Tender, no. hadìth 36.

11 Sahịh Ibn Hibban, hadīth narrated by Abū Hurayrah, Chapter on the remembrance of the ease on the earth revealed by dream to the Messenger, no. hadith 6365. This hadìth is also reported in Musnad Ahmad 7160 
day and to go hungry another,' or he said three days or similar words, 'when I go hungry, I would turn to You in humble entreaty and remember You, and when I am full, I would thank you and praise you..., ,' 12

Furthermore, taking a look into the biography (sirah) of the messenger of Allah, we realize that he mostly lived under a state of lack of material wealth (material poverty) whilst guarding himself and the ummah from being afflicted by normative poverty. He was so bothered by the latter leading to spiritual emptiness $^{13}$ and not the absence of material wealth, as depicted in his oft repeated supplication:

$$
\text { اللّهّمّ مصرّف فَ القلوب صرّف قلوبنا على طاعتك }
$$

"...O Allah, the Turner of the hearts, turn our hearts towards your obedience..." 14

He in fact sought refuge with Allah from normative poverty as in the hadith related by Muslim bin Abī Bakrah wherein the Messenger of Allah (PBUH) is reported to have said:

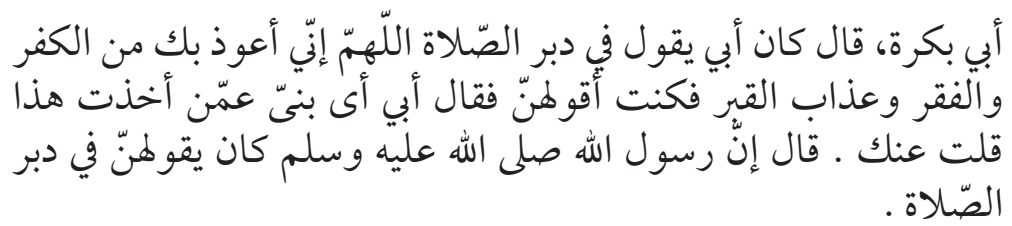

"O Allah, I seek refuge with You from Kufr, poverty, and the torment of the grave,", as part of (His) supplications after every prayer..." 15

12 Jami at-Tirmidhi, hadīth narrated by Abū Umamah, Chapter on Ascetism, no. hadīth 44. This hadīth is also reported in Mu 'jam al-Kabìr, 7835 and in Musnad Ahmad, 22190.

13 This is also the view of some scholars. Scholars like Ibn Wahab, Imam Ahmad, Ibn Uyaynah have earlier opined that the poverty the prophet (PBUH) sought refuge from was poverty of the heart i.e. normative poverty.

14 Sahīh Muslim, hadìth narrated by 'Abd Allāh b. Amr b. al-'As, Chapter of Allah directing hearts as He wills, no. hadith 29. This hadith was also narrated by $\bar{A}$ 'ishah, mother of the believers, May Allah be pleased with her.

15 Sunan al-Nasā'̄ì hadīth narrated by Muslim bin Abī Bakrah, Chapter of seeking refuge with Allah after every prayer, no. hadith 169. 
It is worthy to note that the Prophet (PBUH), who is the best example to follow, ${ }^{16}$ left very little material wealth upon his death; not even for his immediate family - a prophetic characteristic buttressing the aversion for material wealth.

A plausible explanation for the virtuosity of material poverty is that such a state more often than not engenders religious submissiveness, commitment, as well as humbleness towards the Creator. Thus, for a Muslim to preoccupy himself or herself with unjustifiable fears of the absence of material wealth is a wrong doing which will most likely impact negatively on his or religious commitment and culminate into an inability to fulfil his or her purpose of life which is solely to worship Allah. As the Qur'ān states:

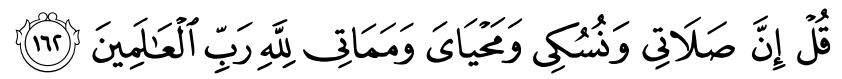

"Say, 'My prayers and sacrifice, my life and death, are all for God, Lord of all the Worlds..."

(Surah al-An‘ām, 6: 162)

Hence, justifiable fear of impoverishment is the fear of normative poverty, which is in fact a condition of richness.

\section{THERAPEUTIC ANTIDOTE FOR NORMATIVE POVERTY}

Categorically, the most fundamental way to remedy normative poverty is to acknowledge Allah's oneness, lordship, and to extol his attributes correctly. ${ }^{17}$ It must be accepted without condition that there is no god but Allah and that Muhammad (PBUH) is the Messenger of Allah, and that He alone deserves worship. ${ }^{18}$ In fact, there are not less than seven or nine conditions requisite to professing the testimony of faith, or words of Divine Unity. ${ }^{19}$ The Muslim pronouncing the shahädah must do so whilst being aware of these conditions. He or she must know the basic meaning of what the testimony means, knowing

16 Qur'ān 33 verse 21, Qur'ān 68 verse 4 and Qur'ān 60 verse 4.

17 This innate concept is called tawhìd under the Islamic Shariah.

18 This is the testimony of faith (Kalimah al-Tawhīd or Shahädatayn). It is to bear witness that there is none worthy of worship except Allah and that Muhammad is His messenger.

19 Some scholars arrived at seven, some stated nine while some arrived at thirteen altogether all based on the primary sources of the Qur'ān and Sunnah. Here, we summarize nine of the conditions. 
what is being affirmed and that which is negated. This condition is labelled the 'knowledge condition'. Evidences for this can be seen in the Qur'ān 47: 19 and 43: 86. He or she must also be certain of the shahädah. This is the condition of certainty deducible from Qur'ān 49: 15, 9: 45, and 35: 26.

A third condition is that of acceptance with one's tongue and heart as well as the implication that emanates from professing it thereof. Evidence for this is seen in the Qur'ān 2: 85. Amongst the condition is that of submission cum compliance which is to physically comply by way of our acts. The rationale for this condition can be found in Qur'ān 39: 54, 4: 65, and 4: 125.

The fourth condition is that of truthfulness, which is to say or profess the shahādah without hypocrisy or dishonesty, for which the Qur'ān also attests to in 2: 8-10. The condition of sincerity is also one of the conditions of professing the shahādah. It denotes saying the shahādah wholly for the sake of Allah. Qur'ān 39 verse 2 and Qur'ān 98 verse 5 confirms this condition. Love is also a condition. This invariably means that a professor of the shahädah must love the testimony of faith, its implications and all that is associated with it or that emanates from it. Verse 165, chapter 2 of the Qur'ān as well as verse 24, chapter 9 of the Qur' $\bar{a} n$ are evidences to this effect. Denying all other objects of worship whilst affirming Allah's oneness in worship is indeed a condition of saying the shahādah and it is the eighth condition. Qur'ān 2 verse 256 confirms this. A ninth condition would be to "stick to" the shahädah till Allah allows death for the professor. In other words, the Muslim who professes the shahādah must adhere to it till death i.e. till he or she dies. Qur'ān 3 verse 102 is a testimony to this condition.

Having established the above, the most comprehensive and potent way of curing normative poverty is to get closer to the Creator. The way to do this has been stated by Allah in a hadìth (e.g. Hadìth Qudsì) wherein the Prophet (PBUH) said:

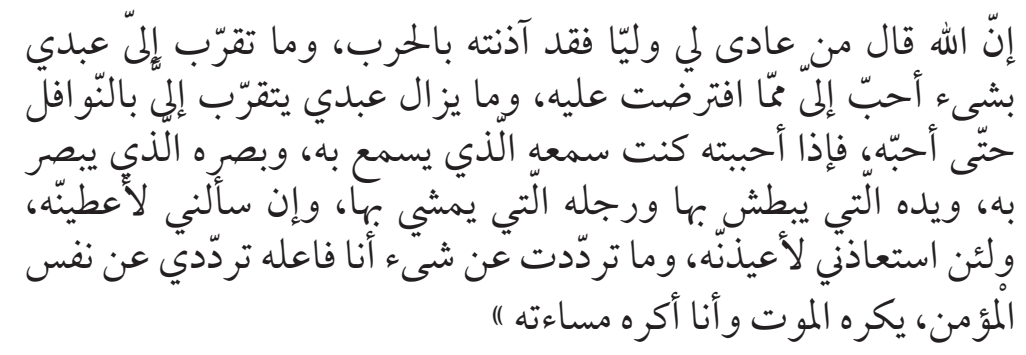

"Allah said, 'I will declare war against him who shows hostility to a pious worshipper of Mine. And the most beloved things with which My slave comes nearer to Me is what I have enjoined 
upon him; and My slave keeps on coming closer to Me through performing Nawafil (praying or doing extra deeds besides what is obligatory) till I love him, so I become his sense of hearing with which he hears, and his sense of sight with which he sees, and his hand with which he grips, and his leg with which he walks; and if he asks Me, I will give him, and if he asks My protection (Refuge), I will protect him; (i.e. give him My Refuge) and I do not hesitate to do anything as I hesitate to take the soul of the believer, for he hates death, and I hate to disappoint him..." 20

Thus by undertaking the compulsory or obligatory duties supplemented with supererogatory duties, the slave of Allah effectively becomes a wali (friend) of Allah and stays clear of adawah (enmity). Such obligatory acts include the five daily prayers, giving compulsory alms (zakāh), fasting in the month of Ramadān, conducting the pilgrimage (hajj) if the physical cum financial capacity exists, honouring and revering one's parents, keeping the ties of family or kinship, enjoining good and forbidding evil, carrying out responsibilities towards wife and children, and trusting in Him (Allah) wholly for His sake, as taught by His Messenger, Muhammad (PBUH).

Avoiding sinful activities or actions which the Creator has prohibited (e.g. engaging in riba, adultery, fornication, promoting injustice and corruption, alcoholism, theft, unnecessary suspicions, backbiting and slander, etc.) are also part of the obligatory duties. Equally, swiftly asking for forgiveness and repenting to Allah when both Allah and man's rights are infringed upon also forms part of these enjoined obligatory duties. Furthermore, complementing the obligatory duties are supererogatory recommended acts which include: reading the non-obligatory prayers (a prescribed number of rak'ahs) after every obligatory prayer, reading the night prayers (tahajjud), undertaking constant remembrance of Allah $(d h i k r)$ as well as a great deal of charitable acts, acquiring beneficial knowledge and teaching it to people, and constantly asking Allah for help by making supplications. Clearly these are intricately linked to matters of faith or the bolstering of faith. By getting closer to Allah via undertaking these noble deeds, one's faith is renewed and increased ${ }^{21}$ which then cures normative poverty and therefore ultimately leads to paradise by the

20 Sahīh al-Bukharī, hadīth narrated by Abū Hurayrah, Chapter of humility, modesty or lowliness, no. hadith 91.

21 Having faith is a requirement to enter paradise. The Prophet (PBUH) was reported to have said; You shall not enter paradise so long as you do not affirm belief i.e. in all those things which are the articles of faith (Șaḥịh Muslim, Book 1, hadìth 101). 
Grace of Allah. Most assuredly, in the remembrance of Allah, the hearts find rest (Qur'ān, 13: 28).

Given the above, the Muslim recognizes the indispensability of seeking knowledge in addressing normative poverty. The Muslim in his quest for seeking knowledge should learn the Names and Attributes of Allah which increases the faith, continually observe and reflect on the signs of Allah "scattered" across the universe, read the Qur'ān in conjunction with the Sunnah of the Prophet (PBUH) extensively and regularly with the right understanding and sincere intention. In essence entering into Islam wholeheartedly is a sure treatment for normative poverty. Allah instructs in the Qur'ān:

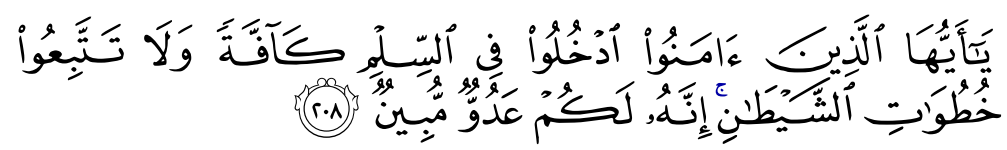

"O you who believe, enter into Islam completely [and perfectly, by obeying all the rules and regulations of the Islamic religion] and do not follow the footsteps of Satan. Indeed, he is to you a clear enemy..."

(Surah al-Baqarah, 2: 208)

\section{CONCLUSION}

By and large, the article has re-explained poverty in the normative way, tried to identify the dimensions of poverty worth dreading, and prescribed therapeutic antidotes for those possessing or harbouring such an absence ${ }^{22}$ which unfortunately happens to be the majority of people today. It is advised that the focus of Muslims should be normative poverty and not an obsession with the absence of material wealth. In fact, a focus on normative poverty by Muslim governments, international organizations, as well as individuals, will create societies of peaceful living, harmonious existence, and brotherly love will guarantee the rights of the human beings as the last Messenger of Allah (PBUH) has said:

$$
\begin{aligned}
& \text { ليس لابن آدم حقّ في سوى هذه الخصال بيت يسكنه وثوب يواري } \\
& \text { عورته و جلف الخبز وألماء }
\end{aligned}
$$

22 The prescription is also applicable or serves as a prophylaxis for potential harbourers or assumers of normative poverty i.e. the true poverty. 
"There is no right for the son of Adam other than in these things: A house which he lives in, a garment which covers his nakedness, and jilf (a piece of coarse bread which has no condiment with it) and water..." 23

To this end, Allah states:

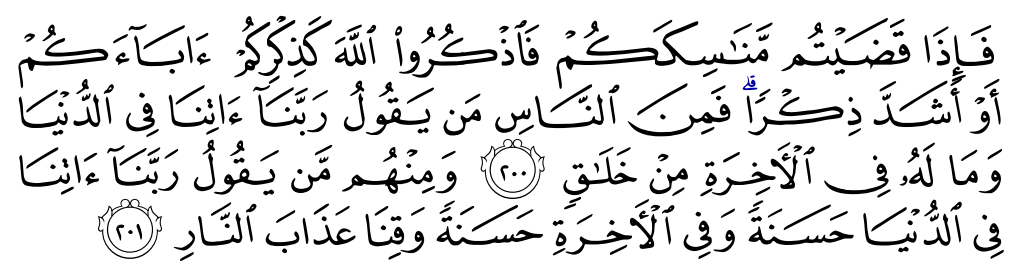

“...but of mankind there are some who say: 'Our Lord! Give us (Your Bounties) in this world!' and for such there will be no share in the Hereafter. But of them are some who say: 'Our Lord! Give us in this world that which is good and in the Hereafter that which is good, and save us from the torment of the Fire!",

(Surah al-Baqarah, 2: 200-201)

suffices as grand conclusion. To this effect, the following hadiths best summarize the theme of this paper. Narrated Abū Dharr, the Prophet (PBUH) said:

$$
\begin{aligned}
& \text { قال رسول الله: يا أباذر آترى كثرة المال هو الغني؟ قلت نعم يا رسول الله }
\end{aligned}
$$

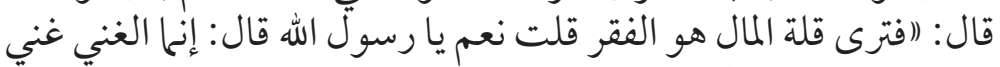

$$
\begin{aligned}
& \text { القلب و الفقر فقر القلب فلم الب الب }
\end{aligned}
$$

"True poverty is the poverty of the heart and true richness is the richness of the heart..." 24

Anas bin Malik narrated that the Messenger of Allah (PBUH) said:

$$
\begin{aligned}
& \text { من كانت الآخرة همّه جعل الله غناه في قلبه وهمع له شمله وأتته الدّنيا }
\end{aligned}
$$

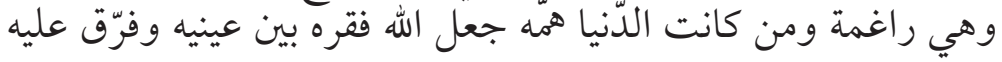

23 Jami' at-Tirmidhi, hadith narrated by 'Uthman bin 'Affan, Chapter of The Things For Which The Son of Adam Has No Right Over Other Than Them, no. hadìth 38).

24 Sahịh Ibn Hibban, hadìth narrated by Abū Dharr, Chapter on the remembrance of the book of Allah and enjoining Muslims to be patient on what has been endowed for them, no. hadìth 685 . 


$$
\text { شمله ولم يأته من الدّنيا إلاّ ما قدّر له. }
$$

"Whoever makes the Hereafter his goal, Allah makes his heart rich, and organizes his affairs, and the world comes to him whether it want to or not. And whoever makes the world his goal, Allah puts his poverty right before his eyes, and disorganizes his affairs, and the world does not come to him, except what has been decreed for him..." 25

\section{PERTINENT SCRIPTURES FOR CONTEMPLATION}

"Know that the life of this world is only play and amusement, pomp and mutual boasting among you, and rivalry in respect of wealth and children. It is as the likeness of vegetation after rain, thereof the growth is pleasing to the tiller; afterwards it dries up and you see it turning yellow; then it becomes straw. But in the Hereafter there is a severe torment for the disbelieving evildoers, and there is forgiveness from Allah and His Good Pleasure for the believing gooddoers. And the life of this world is only a deceiving enjoyment:

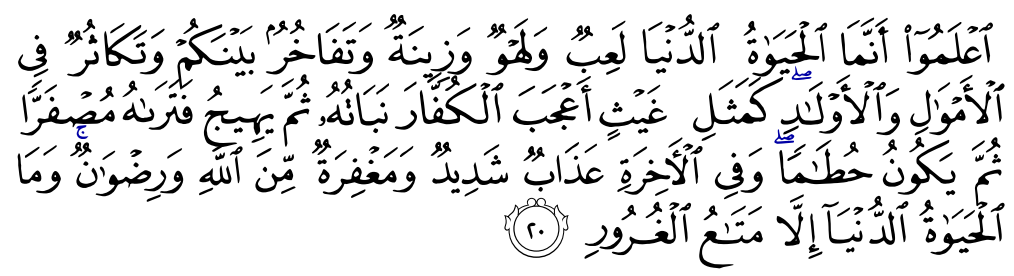

"And put forward to them the example of the life of this world: it is like the water which We send down from the sky, and the vegetation of the earth mingles with it, and becomes fresh and green. But (later) it becomes dry and broken pieces, which the winds scatter... and Allah is Able to do everything. Wealth and children are the adornment of the life of this world. But the good righteous deeds that last, are better with your Lord for rewards and better in respect of hope..."

(Surah al-Ḥadīd, 57: 20)

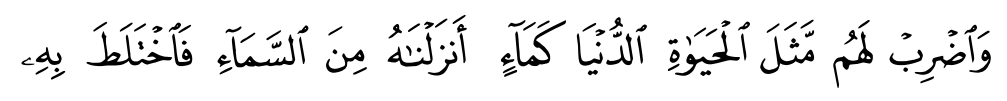

25 Jami` at-Tirmidhi, hadīth narrated by Anas Ibn Malik, Chapter on the description of the day of judgement, heart softening/tendering and association, no. hadith 2653. 


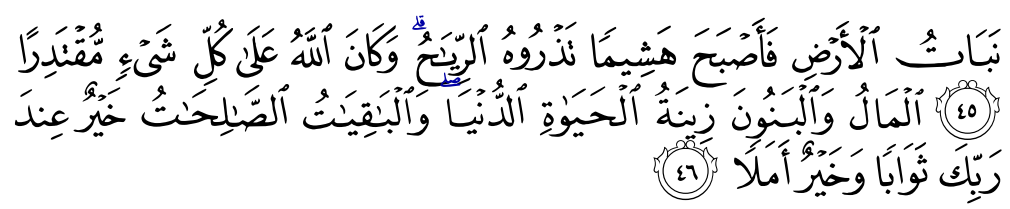

"And present to them the example of the life of this world, [its being] like rain which We send down from the sky, and the vegetation of the earth mingles with it and [then] it becomes dry remnants, scattered by the winds. And Allah is ever, over all things, Perfect in Ability Wealth and children are [but] adornment of the worldly life. But the enduring good deeds are better to your Lord for reward and better for [one's] hope..."

(Surah al-Kahfī, 18: 45-46)

'Abd al-Raḥman bin Aban bin 'Uthmān bin 'Affan narrated that his father said: "Zayd bin Thābit departed from Marwan at mid-day. I said: 'He has not sent him out at this time of the day except for something he asked.' So I asked him, and he said: 'He asked me about some things we heard from the Messenger of Allah (PBUH) say:

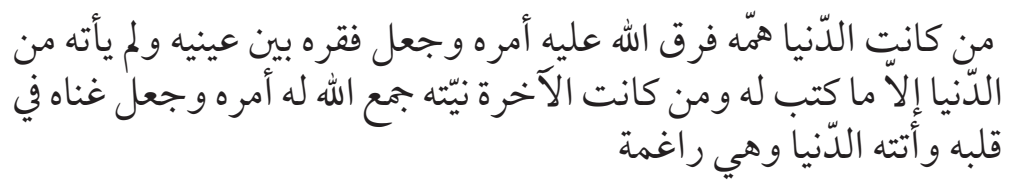

"Whoever is focused only on this world, Allah will confound his affairs and make him fear poverty constantly, and he will not get anything of this world except that which has been decreed for him. Whoever is focused on the Hereafter, Allah will settle his affairs for him and make him feel content with his losses, and his provision and worldly gains will undoubtedly come to him.", 26

Uqba b. 'Amir reported Allah's Messenger (PBUH) as saying:

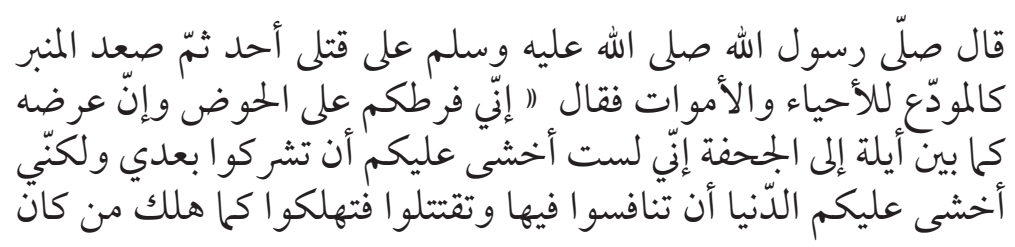

26 Sunan Ibn Mājah, hadīth narrated by Abdur-Rahman bin Aban bin 'Uthman bin 'Affan, Chapter on Ascetism, no. hadith 4244. 


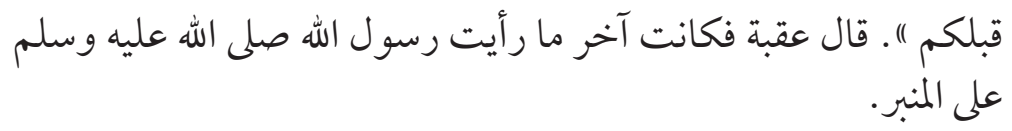

"Allah's Messenger offered prayer over those who had fallen matyrs at Uhud. He then climbed the pulpit as if someone is saying good-bye to the living and the dead, and then said: 'I shall be there as your predecessor on the Cistern before you, and it is as wide as the distance between Ayla and Juhfa (Ayla is at the top of the gulf of 'Aqabah). I am not afraid that you would associate anything with Allah after me, but I am afraid that you may be (allured) by the world and (vie) with one another (in possessing material wealth) and begin killing one another, and you would be destroyed as were destroyed those who had gone before you. 'Uqbah said that that was the last occasion that he saw Allah's Messenger on the pulpit..." 27

Abū Hurayrah narrated that the Messenger of Allah (PBUH) said:

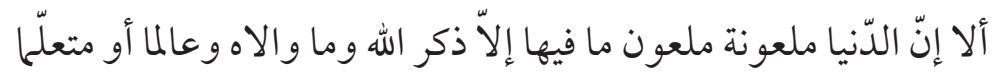

"This world is cursed and cursed is what is in it, except for the remembrance of Allah Almighty and what brings one near to Him (i.e. what is conducive to that) or one who has knowledge or who acquires knowledge..." 28

'Abd Allāh bin Mas' $\bar{u} d$ narrated that the Messenger of Allah (PBUH) said:

$$
\text { لا تتّخذو ا الضّيعة فترغبو ا في الدّنيا }
$$

"Do not take possession of estates or you will find yourselves seeking after this world..." 29

It was narrated from Hārithah bin Mudarrib:

$$
\text { إنّ العبد ليؤجر في نفقته كلّها إلاًّ في التّراب }
$$

27 Sahīh Muslim, hadīth narrated by Uqba b. 'Amir, Chapter of the Cistern Of the Prophet (SAW) and Its Attributes, no. hadith 38.

28 Jami at-Tirmidhi, hadīth narrated by Abū Hurayrah, Chapter on Asceticm, no. hadìth 19.

29 Jami' at-Tirmidhi, hadīth narrated by 'Abd Allāh bin Mas'ud, Chapter on Asceticm, no. hadith 25. 
".....A person will be rewarded for all his spending, except for (what he spends) on building..." 30

Jabir b. 'Abd Allāh reported that Allah's Messenger (PBUH) said:

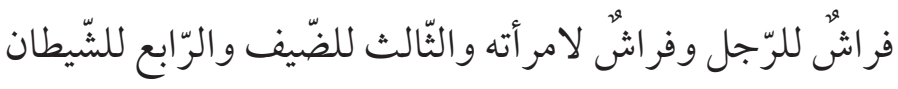

"There should be a bedding for a man, a bedding for his wife, the third one for the guest, and the fourth one is for the Satan..." 31

It was narrated from Anas Ibn Mālik that the Messenger of Allah (peace and blessings of Allah be upon him) said:

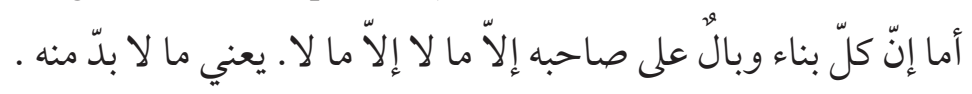

"Every building is a misfortune for its owner, except what cannot, except what cannot, meaning except that which is essential or necessary..." 32

The Prophet (PBUH) said to Sa'd bin Abū Waqqas:

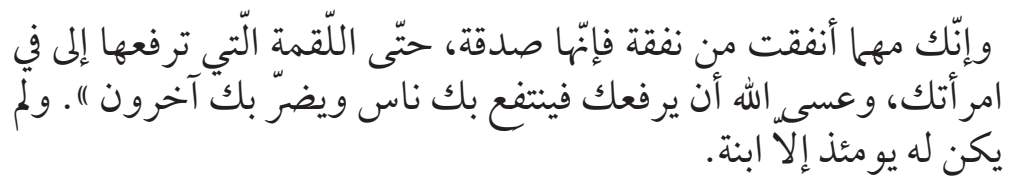

"....know that you will never spend anything seeking thereby the Countenance of Allah, but you will be rewarded for it, even (the food) that you put in your wife's mouth." 33

30 Sunan Ibn Mājah, hadīth narrated by Ḥārithah bin Mudarrib, Chapter on Ascetism, no. hadìth 4302. The hadìth is also reported in; Al-Adab Al-Mufrad 455: Book 25, hadìth 14, Șahīh al-Bukharī, 5672: Book 75, hadìth 33; Jami`at-Tirmidhi; Book 37, hadith 2671.

31 Șahīh Muslim, hadīth narrated by Jabīr b. 'Abd Allāh, Chapter on being disliked to have beddings and furniture more than one needs, no. hadith 67. A similar message is reported in; Sunan Abī Dawud 4142, Book 34, hadīth 123. Sunan anNasa'i 3385, Book 26, hadīth 190.

32 Sunan Abī Dawud, hadīth narrated by Anas Ibn Malik, Chapter regarding building, no. hadìth 465. Also narrated in Sunan Ibn Mājah, Book 37, hadìth 4300.

33 Șahịh al-Bukharī, hadīth narrated by Sa'd bin Abū Waqqas, Chapter on wills cum testament, no. hadìth 5. Also reported in Sunan an-Nasa'i 3631, Book 30, hadìth 21; Șahīh al-Bukharī, 1295, Book 23, hadīth 54; Șahīh Muslim, 162, Book 25, hadīth 6; Sahīh al-Bukharī, 6733, Book 85, hadīth 10; Sunan Abī Dawud 2864, Book 18, hadìth 3. 


\section{REFERENCES}

al-Bukhari, M., al-Adab al-Mufrad (English-Arabic) trans. R. Abdur Rahman (Lebanon: Dār al-Kutub al-'Ilmiyyah, 2011).

al-Nasa'i. H.A., Sunan al-Kubra (Beirūt: Muassasah al-Risālah, n.d.).

At-Tirmidhi, H. M., Jami ‘ al-Tirmidhi (English-Arabic), trans. Abū Khaliyi (Saudi Arabia: Darussalam, 2007).

Dawud, A. S., Sunan Abu Dawud (English-Arabic), trans. Yaser Qadhi (Saudi Arabia: Darussalam, 2008).

al-Hakim, A. A., al-Mustadrak 'ala al-Ṣaḥịhayn (Beirūt: Dār al-Ma'rifah, n.d.)

Hanbal, A. I. M. I., Kitāb al-Zuhd (Yemen: Maktabah al-Iyaman, 1970).

Hanbal, A. B., al-Musnad Aḥmad bin Hanbal (Beirūt: Dār al Fikr, 1981).

Ibn Abī al-'Izz, Sharh al-'Aqīdah al-Tahawiyyah (Saudi Arabia: al-Imam Muhammad Ibn Sa'ud Islamic University, 2000).

Ibn Abī Shaybah, al-Musannaf fì al-Ahādīth wa al-Athār li al-Hafìz (Beirūt: Dār al-Fikr, 2008).

Ibn Hibban, B.M., Șaḥ̄ḥ Ibn Hibban (Beirūt: Dār al-Kutub al-'Ilmiyyah, n.d.).

Ibn Khuzaymah, Șaḥ̄h Ibn Khuzaymah (Beirūt: Dār al-Kutub al-'Ilmiyyah, n.d.)

Ibn al-Qayyim, Tuhfah al-Mawdūd bi Ahkām al-Mawlūd (Beirūt: al-Maktabah al-Assrya, n.d.).

Mājah, M. A., Sunan Ibn Majah (English-Arabic), trans. al-Khattab N. (Saudi Arabia: Darussalam, 2007).

Muslim, H. N., Sahih Muslim (English-Arabic), trans. N. Khattab (Saudi Arabia: Darussalam, 2007).

al-Nasa'i. H.A., Sunan al-Nasa'i (English-Arabic), trans. al-Khattab N. (Saudi Arabia: Darussalam, 2007).

Philips, A.B., Ușūl al-Tafsīr (Saudi Arabia: International Islamic Publishing House, 2005).

Philips, A.B., Ușūl al-Hadìth (Saudi Arabia: International Islamic Publishing House, 2007).

Sa'd, M. I., al-Tabaqat al-Kubrā (Beirūt: Dār al-Kutub al-'Ilmiyyah, 1997).

Saidu, O. S., 'Poverty in Nigeria As A Prima Facie of Rule Non Compliance,' Journal of Advanced Social Research, vol. 4/8 (August 2014): 1-20.

Al-Tabarani, S. A., al-Mu jam al-Awsat, ed. T. al-Husayn̄̄ (Cairo: Dār alHaramayn, 1994). 
Al-Ṭabarān̄i, S. A., al-Mu 'jam al-Kabīr (Cairo: Maktabah bin al-Taymiyyah, 1994).

The Qur'ān: Muhsin Khan Translation (Riyadh: Muktabah Darusslam, 1996). The Qur'ān: Saheeh International Translation (Riyadh: al-Muntada al-Islami Trust, 2012). 
Jurnal Syariah, Jil. 25, Bil. 1 (2017) 117-136 